\title{
AN INTEGRATED APPROACH BASED ON TRADITIONAL ARCHAEOLOGICAL SURVEYS, DIGITAL RECORDING TECHNIQUES AND HISTORICAL DOCUMENTATION FOR THE ASSESSMENT OF THREATS RELATED TO THE CLIMATE-SENSITIVE TERRITORIAL CONTEXT
}

\author{
C. Stanga ${ }^{a *}$, R. Valente ${ }^{b}$, M. Previtali ${ }^{b}$ \\ a Politecnico di Milano, Graduate School in Architectural and Landscape Heritage - (chiara.stanga)@mail.polimi.it; \\ b Politecnico di Milano, Department of Architecture, Built Environment and Construction Engineering, \\ Via Ponzio 31, 20133 Milano, Italy - (riccardo.valente; mattia.previtali)@polimi.it
}

KEY WORDS: Built Heritage; Risk and Resilience; Documentation; Archaeological Sites; Terrestrial Laser Scanning; Photogrammetry

\section{ABSTRACT:}

This essay describes an integrated approach - field survey, historic research, climate data, and topography - for the analysis of a complex stratigraphical archaeological site, highlighting its peculiar aspects and its conservation state, and contributing to the studies of this area.

The case study is San Calocero monastery in Albenga, one of the most important historical evidence of the city, located on the San Martino Hillside, dating back to the VI century but with a complex historical stratigraphy until the XVI century, along with other relevant archaeological sites, such as the Baptistery, the Ponte Lungo, the churches of San Clemente and San Vittore, which, as long as San Calocero, went through several changes over the years.

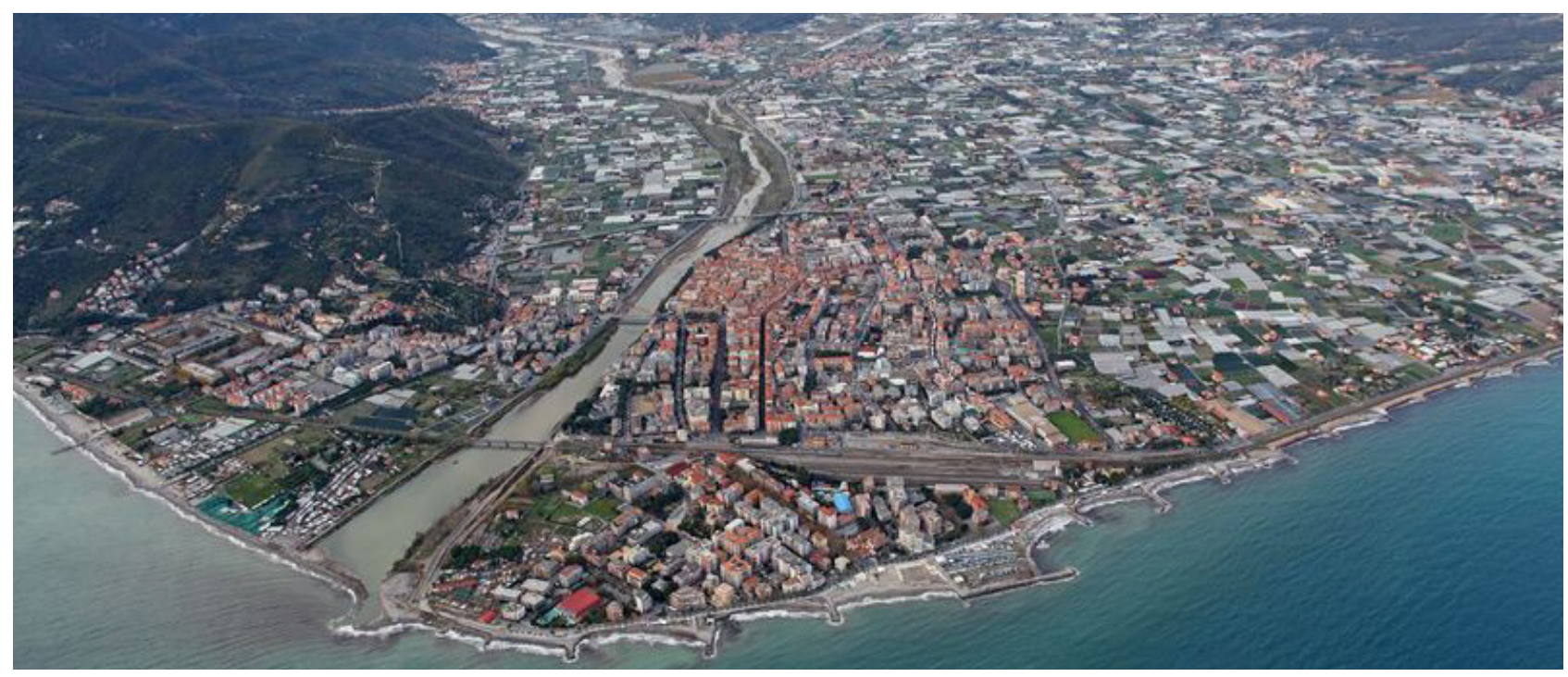

Figure 1. Aerial view of Albenga

(http://www.savonanews.it/fileadmin/archivio/savonanews/festa_bandiera_albenga_2.JPG)

\section{INTRODUCTION}

The object of this study is the monastery of San Calocero in Albenga with the goal of expanding the existing knowledge on the building itself and its territory through a 'global' approach that involves different disciplines and sources.

This paper presents the first results of a larger analysis project that will be finalized in the next months.

\section{CASE STUDY}

\subsection{The town of Albenga}

Founded by the Romans between the end of the second and the beginning of the first century B.C., Albenga (Figure 1) is an historical settlement located in the western part of the Ligurian
Region, which had a prominent role during the Roman Empire due to its harbor, one of the most important of the whole area (Massabò, 2010; Pergola, 2010).

Its built heritage is made of many important archaeological sites, like the Via Julia Augusta and its Roman ruins, the monastery of San Calocero, the church of San Clemente, the church of San Vittore and the Baptistery.

Although their historical and cultural relevance is well-known, they are subject to constant and severe decay.

Albenga's landscape is the result of both slow and unexpected changes occurred over time due to floods, natural calamities, and coastal erosion. Furthermore, human activities contributed to shape the territory.

The town and its territory is an interesting case study for three main reasons: its landscape, characterized by the Centa River Valley, surrounded by hills, and touched by the sea; the great

$1 *$ Corresponding author 
relevance of its archaeological sites, that prove the long-term human presence; several existing studies and publications about its built and landscape heritage, which provide a large sets of data.

\subsection{San Calocero monastery}

San Calocero's site is located on a hillside near the town of Albenga, facing the Via Julia Augusta. Probably erected on a former funerary area where the martyr Calocero was buried, the church was presumably built during the VI century and later renewed during the Early Middle Ages. In the XIV century it became property of the Benedectines (from the XV century Order of Saint Clare) until the end of XVI century (Embriaco, 2010), when the nuns moved to a new monastery inside the town-wall, because the old one was considered improper for monastic life (Vignola, 2010). In XVII century (1607) the structure became privately owned by one of the most influential local families, the Peloso Cepollas, and was progressively abandoned (Gavinelli, 2010; Vignola, 2010).

The site is arranged on four terracing levels, of which the first and the fourth are currently open areas. The current entrance to the site brings to the second level, where a great wall made of stones and mortar - with a recess in the middle where an ancient sarcophagus is located - serves as retention barrier. From the entrance, it is possible to see the apsis of the church, the nave and the aisle. The whole area was enclosed with a wall, north-south oriented, still visible (Figure 2). It is still not sure if the church had one or two aisles (Pergola, 2010). In the third level there is an interesting space, called 'criptoportico' (Figure 9), that was probably covered with vaults - as some remains suggest - and it is opened towards the fourth level (now is privately owned) through a structure made of arches supported by pillars. The uphill side of this structure is a Roman retaining wall, which presents some tubi fittili (clay elements) that were part of the water drainage system. Following the current visiting path, from the 'criptoportico' it is possible to descend to a intermediate level, where there is an open space, that was probably covered with vaults, characterized by a pebble flooring (with a drainage ditch). There is also a water tank and a oven (kitchen). From the second level, along the north-south oriented wall, it is possible to get into the upper open area, probably used as a vegetable garden (Landi, 2010).

Graves were found in the proximity of the apsis, in the 'criptoportico', and in front of the main façade. Other findings include some supplies and liturgical furniture, like the elements of the altar.

The site is characterized by many archaeological stratifications which are evidences of the past changes and transformations.

\section{METHODOLOGY APPROACH}

The methodology used to carry out the research on the San Calocero monastery is based on an integrated approach that helps capture the different stratigraphy and changing complexity of the archaeological site. The monastery went through many changes from the VI to the XVI century, and it is still possible to find traces of this events on its ruins.

This multidisciplinary approach includes surveys, historical research, topography, and climate data, because each of this method gathers different 'signs' of the archaeological site (Figure $3)$. This means there is a continuous comparison between 'direct' sources (surveys and measurements of the monument itself through traditional and advanced surveys techniques, like laser scanning and photogrammetry) and 'indirect' sources (historical research, climate data, topography) that allows interpretations about the archaeological site and its present and past arrangements to emerge (Boato, 2008).

Furthermore, the possibility to study an archeological site that still shows its complex stratification from the VI to the XVI century, along with the presence of historical documents stored in archives, is a great opportunity to compare all sources in situ. This study aims to deepen the knowledge we have of the last phases of the building, starting from 1593 when the nuns moved in a monastery inside the town-wall and covering the year 1607 when they sold their properties on San Martino Hill, including San Calocero, to Prospero Peloso Cepolla.

This can be achieved by recording the exact measure of the 'signs'

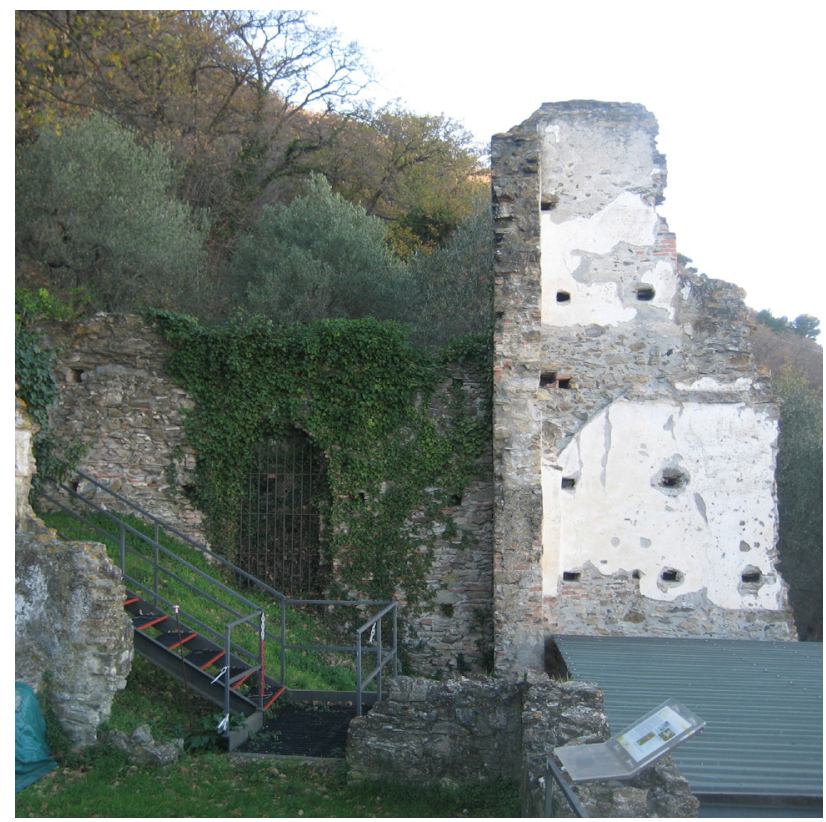

Figure 2. San Calocero (January 2017 by Chiara Stanga)

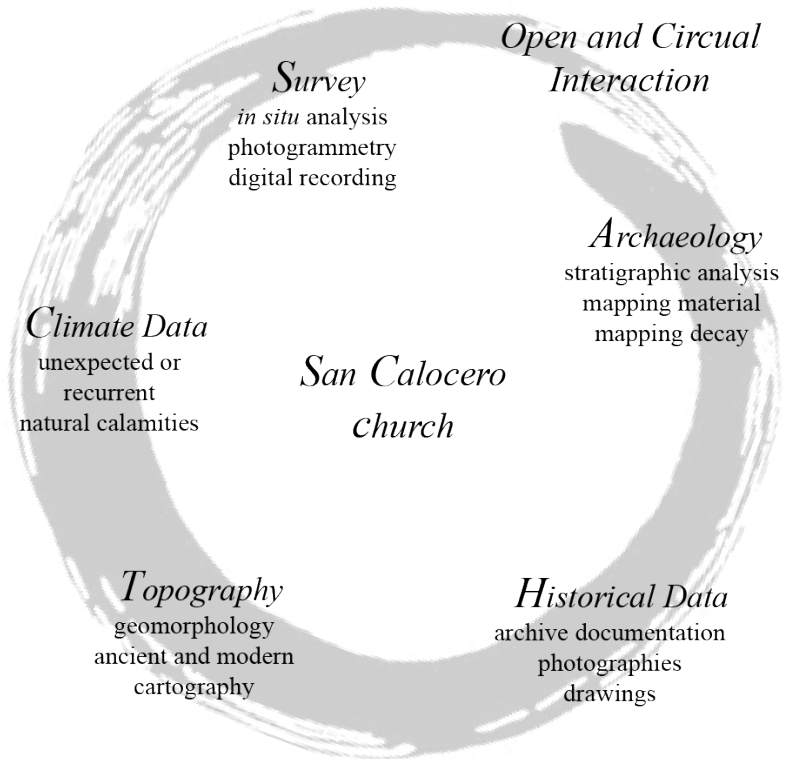

Figure 3. Circular interaction between disciplines 
of the building and correlating them to historical and climate data by looking at previously studies about the archaeological site, and past and present climate recordings. The idea is to understand if and how the building suffered damages or collapses, and if this was the reason behind its abandonment.

The sale agreement found in Peloso Cepolla's archive shows that the monastery was already in a bad state of conservation when he bought it. However, it is fundamental to proceed with further research to understand if Peloso Cepolla made some restoration works or changes. In fact, some remains suggest that parts of the archaeological site were still used in the XVIII century, like the area with the oven - kitchen (Roascio, Gavagnin, 2010). In order to further investigate this, a deep focus on the stratigraphic analysis of the most recent phases will be carried out in order to provide additional information on the possible correlation between the material decay and the influence of the climate changes.

At the same time, it is important to understand the "constructive model' of the building by deeply studying the material and construction techniques, through the Bauforschung approach: recordings of three-dimensional structures are converted into two-dimensional drawings based on exact measurements (De Mattia, 2012). The correlation between exact measurements and its graphical representation is interesting because it highlights the complexity of the site and translates it into 'interpretative models' (Figure 4).

Due to the previous reasons, the study requires appropriate instruments, supported by a solid methodology described above. For obvious reasons, the instruments change over time because of the progress made by technology and are influenced by the researcher's skills and the available means. For e.g, Nino Lamboglia, the archaeologist who first did the excavation in the area in the 1930s, performed a stratigraphical excavation - an advanced method for that time - that analyzed the successive layers of the site, but paid less attention to the most recent deposits that covered the building, avoiding further analysis about the collapse events (Roascio, 2010).

Also, it is important to keep 'congruity' between the research and the object of the study, that means to find appropriate instruments and 'conceptual models' to analyze the object, i.e. San Calocero, correlating the different studies to the archaeological site.

Although strictly intertwining 'direct' and 'indirect' sources, this methodology can only result in 'probabilistic' conclusions, because it is based on 'abductive inference' (Boato, 2008; Gallina, 2012).

In fact, this study focuses not so much on providing answers to the many pending questions on San Calocero, but to open new research horizons to help better understand this important archeological site through an 'hermeneutic approach' between all involved resources and existing studies.

This methodology consists of several steps: (i) the identification of the 'signs' of the building, (ii) their interpretation, (iii) the realization of a 'conceptual model', (iv) the creation of correlations between 'signs' and possible causes.

\section{INVOLVED KNOWLEDGE BASES}

\subsection{Survey}

4.1.1 Survey - Background: Surveys are an important step in the study of a building: its measurement and representation is the basis for its comprehension (Schmidt, 2002).

The San Calocero monastery has been studied for almost a century, from the first excavations by Lamboglia in the 1930s to the ones occurred in the 1980s and the last ones in 2014 and 2015 led by Philippe Pergola. All of these surveys used different instruments and gave different representations of the building. Lamboglia, who is considered one of the innovators of the Italian archaeology (Paltineri, 2007), performed three excavations in the area: in 1934, in 1938-39, and in 1970-71. He used a stratigraphical method that was innovative at that time, studying not only the layers that were considered relevant by the Classical Archaeology, but also more recent ones, till the Middle and Modern Ages (Roascio, 2010).

During the 1938-39 survey, most of the building were studied, including its stratigraphy and elevations. During the 1980s (1985-1991) seven fieldworks in restricted areas were performed which brought to light graves, sarcophagi, and other findings.

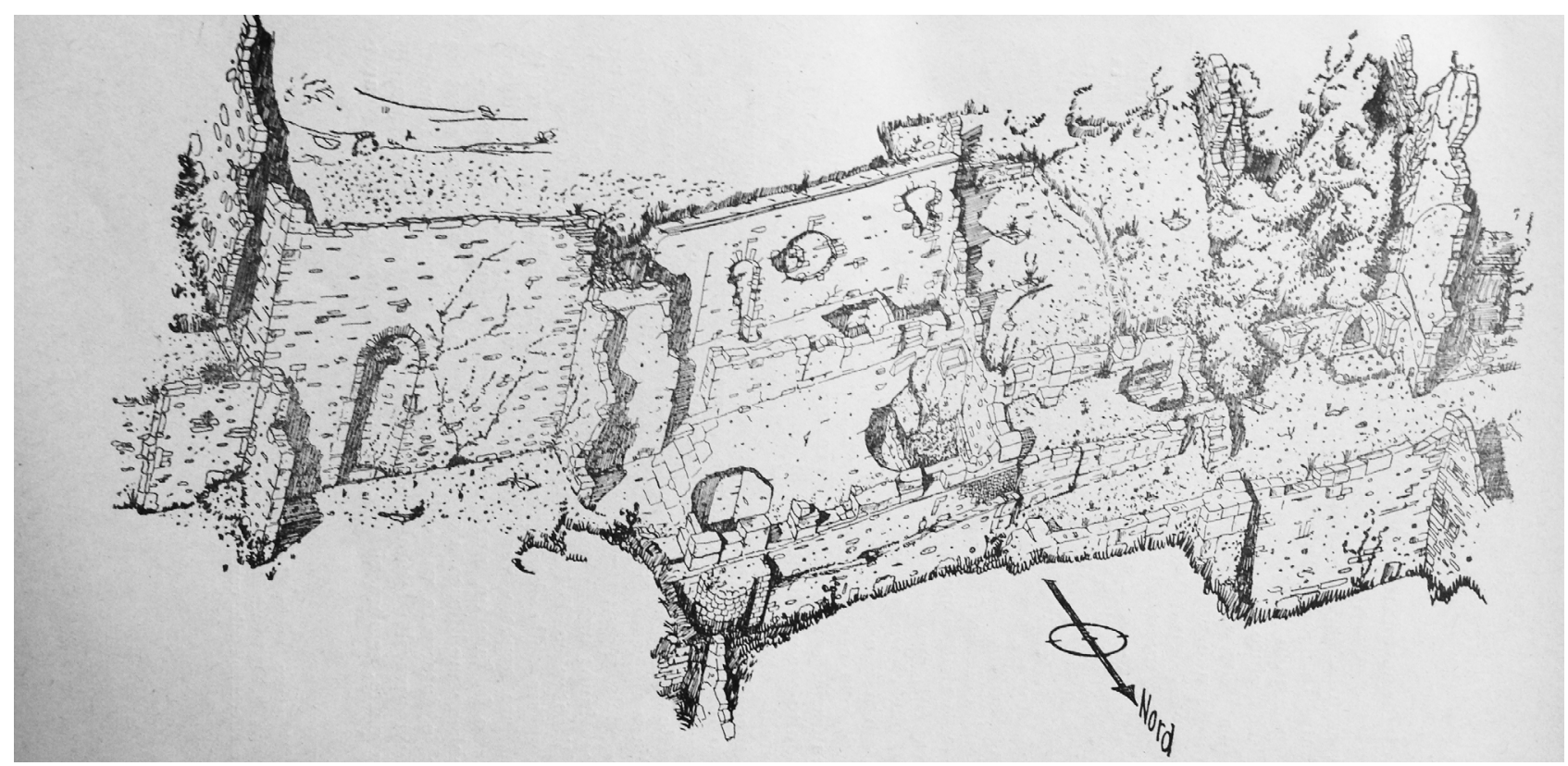

Figure 4. Axonometric view of San Calocero

(Lamboglia N., 1947. Gli scavi nella zona paleocristiana di S. Calocero (Albenga). In: Rivista di Studi Liguri, anno XIII, p. 143) 
Surveys were executed with traditional instruments, such as topographical and hand measurements. The starting point for the current analysis includes the results already published (Spadea Noviero et al., 2010).

In 2015 the Graduate School of Architectural and Landscape Heritage applied advanced instruments (provided by Gicarus Lab) to record the archaeological site, such as laser scanning and photogrammetry. A local geodetic network, combining total station and GPS measurements, was used to obtain precise georeferenced data, together with laser scanning (Faro Focus 3D) and photogrammetry.

In particular, fifty-two registered scans were acquired, and then registered using also geodetic network data, to cover the entire area of the complex, from the lower to the upper level, limiting the presence on the site to only one day.

Starting from point clouds, it was possible to realize architectural plans and sections of existing structures, integrating older plans realized a decade ago (Figure 5).

Digital Photogrammetry (Agisoft PhotoScan) was used to document the different steps of the excavation process in the four trenches opened during the 2014-2015 campaings, together with some traditional sketches (Figure 6). It was also used to analyze the visible elevations providing three-dimensional models and orthoimages that can be used for the stratigraphic and material decay analysis (Figure 7).

4.1.2 Survey - Goal: The goal is to correlate material decay and stratigraphic analysis in order to correctly interpret 'signs', relating them to the historical documents.

Furthermore, a pure 'architectural study' of this site is still missing. As part of future research, it would be interesting to analyze architectural elements, such as the remains of the vaults in the 'criptoportico', the surface finishing and constructive materials, bricks and stones, their composition and their traceability, and water drainage devices.

Another subject for future studies would be the influence of digital techniques and 3D models on the recording and representation of the site geometrical and stratigraphic complexity, taking into consideration present and past arrangements.

\subsection{Historical research}

4.2.1 Historical research - Background: This phase includes the study of the existing documentation. Most of the existing documentation is collected in a recent publication (Spadea Noviero et al., 2010).

Another important source of information are the fieldwork reports (not completely published) written by Lamboglia. Also, the main source of information is the State Archive of Torino, in which only a part of the monastery's archive is preserved. In fact, its majority has been lost over the centuries. Other sources include the Municipality Archive, the Diocesan Archive, and the State Archive of Genova (Vignola, 2010).

4.2.2 Historical research - Goal: The goal is to analyze the last period of the life of the monastery, its abandonment, and the latter phases, which have not been fully investigated before. As mentioned above, in 1607 the Order of Saint Clare sold the monastery to Prospero Peloso Cepolla, who was one of the 'protectors' of the nuns together with Vincenzo d'Aste and Francesco Cazulino, other influential local families (Raimondi, manoscritto 44).

In the sale agreement (Figure 8), it is written that the monastery was in a very bad state of conservation and needed restoration, but the nuns did not have enough money to restore it.

Further time and research have to be invested in the study of the document preserved in the Peloso Cepolla Archive in order to find more information. In addition, the sale agreement shows that Prospero Peloso Cepolla had other properties on the hillside of San Martino Hill.

Further studies could be carried out to compare the 1553 property inventory with the 1613 one in order to verify which properties Prospero already had and which ones he bought from the nuns.

\subsection{Environment and climate data}

4.3.1 Environment and climate data - Background: Albenga's landscape is the result of different factors at play, such as river, and sea, and it went through different changes during the

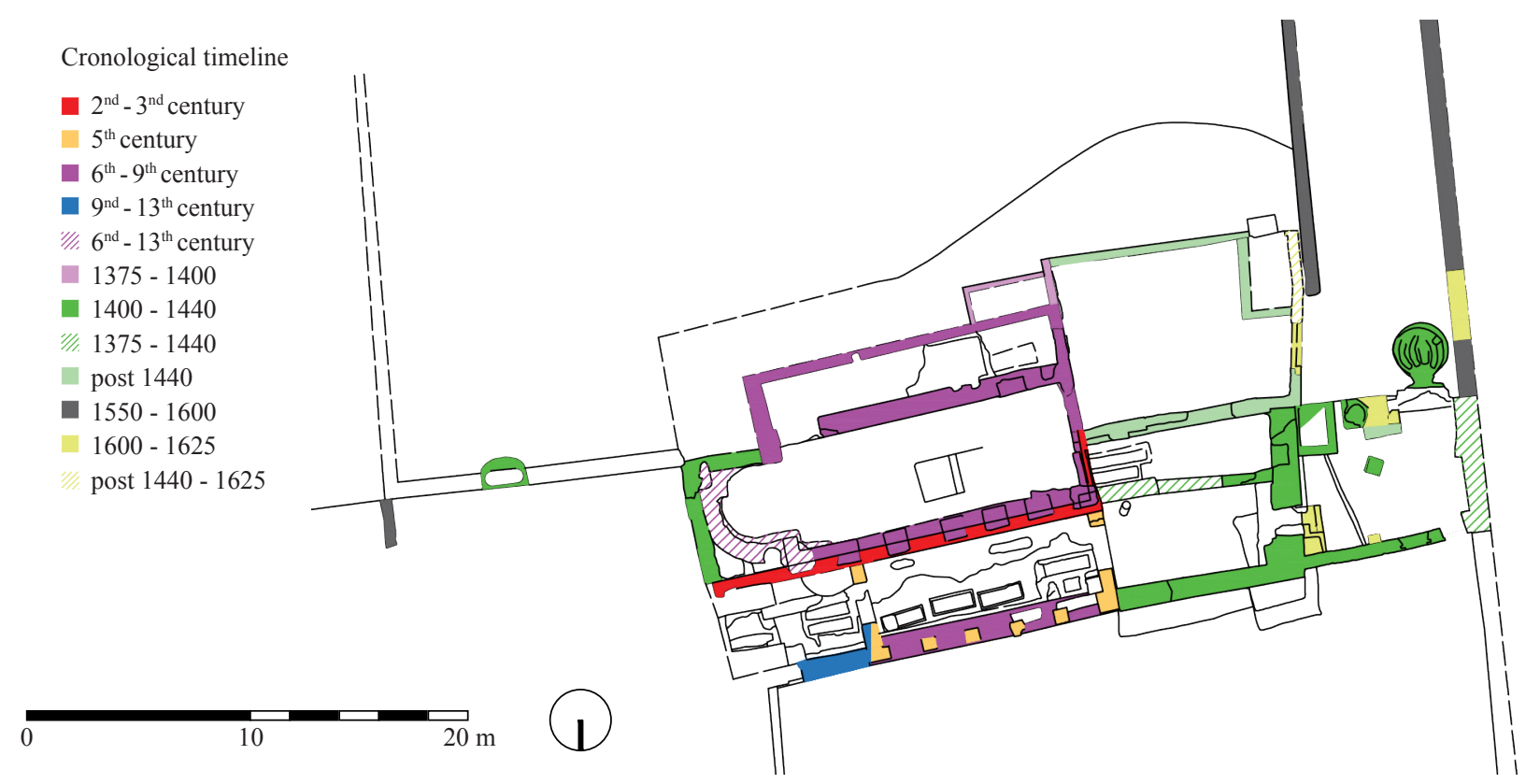

Figure 5. San Calocero's plan with the chronological phases (drawing is based on the laser scanning survey occured in 2015, while the chronological timeline is taken from: Spadea Noviero et al., 2010. Albenga, Fratelli Frilli Editori, Genova p. 212) 
centuries due to human activities and to the presence of the Centa River, whose path endured many transformations.

Influenced by Ligurian sea and River Centa, the topography of the landscape changed over time and is still undergoing trasformations, due to floods and precipitations.

In fact, Roman evidences, are approximately located at four metres below the actual ground: this shows that many floods brought important amounts of sediments (Lamboglia, 1970; Arobba et al., 2006).

Western Ligurian Region has also been affected by earthquakes, the most known of which is the one occurred in 1887 and whose epicenter was located in the sea (Solarino, 2007).

4.3.2 Environment and climate data - Goal: Natural calamities have always influenced the conservation of the archaeological site and this topic is now more important than ever.

The site appeared to be already widely ruined during the 1930s, when the first excavation was carried out.

Established on a steep hillside, the location has probably played a role in the abandonment of the site and in today's increased degradation. Today it seems to be lacking a thought-out conservation plan, and the exposed surfaces are vulnerable to constant decay, caused by sudden and heavy rainfalls, which are an increasingly frequent event.

In critical occasions, the different levels of the building become some sort of pools, transporting the water from one floor to another.

In order to have an overview of all the natural calamities that have affected San Calocero, it is necessary to collect information about the territory, its morphology and past events.

Some data on how the river shaped the surrounding territory can be found in existing literature, alongside historical cartography (Arobba 2004, 2006; Quaini 1986).

Other information can be found in local chronicles (e. g. Manoscritto Borea, from the Borea family, which reports the main earthquakes occured between the XV and the XIX century in Sanremo and the Western Ligurian Region) that can be helpful to have a qualitative understanding of the past natural calamities, even without providing 'scientific recordings'.

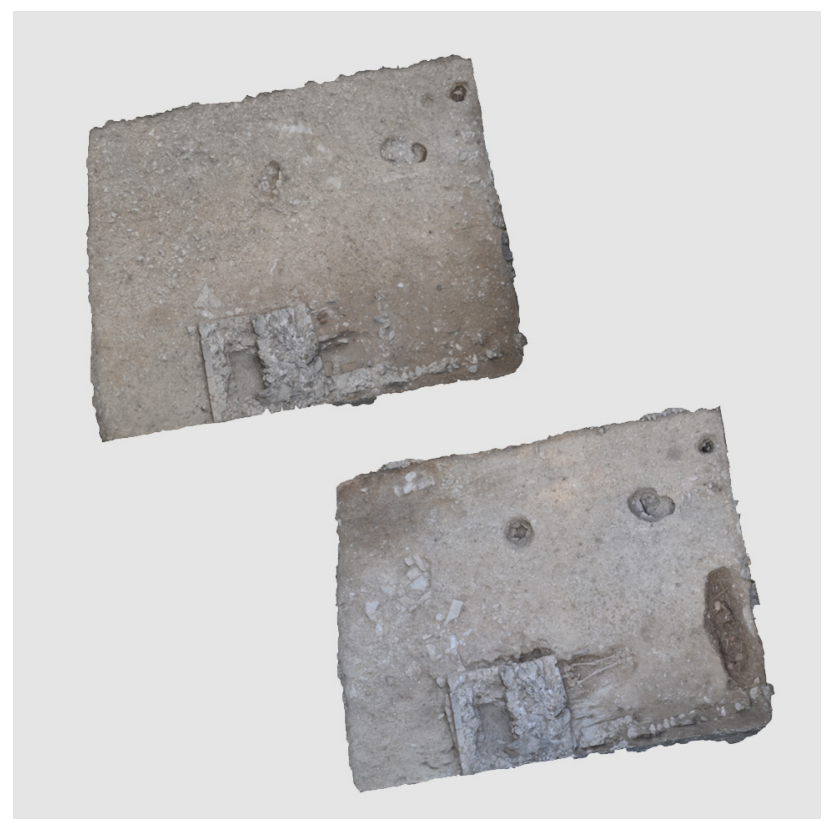

Figure 6. Two levels of the excavation area during the last survey (2015)

\section{FUTURE PERSPECTIVES}

This research offers an integrated and 'global' approach to the archaeological site of San Calocero, where each involved discipline provide a specific set of skills that are combined to analyze the different aspect of the complex building.

This allows the highlighting of some phenomena, e.g. the interaction between material decay, climate and morphological changes, and opens new questions. For example, what kind of collapse occurred in San Calocero? Gradual and extensive or unexpected and confined? Was it abandoned because of the collapses? Did the site have structural weakness? What was their real arrangement?

Furthermore, it would be interesting to expand this approach to other archaeological evidences in Albenga, such as the Baptistery and the Ponte Lungo, in order to have a wide picture of the changes occurred in the buildings over the years.

The study of 'key sites', together with the investigation on natural calamities (unexpected or recurrent), and historical research, offers interesting starting point to understand the different arrangements and transformations occurred in Albenga.

The knowledge of the past events is fundamental to understand present phenomena, foresee future events, and design a correct plan for the site conservation.

\section{CONCLUSION}

This essay can be considered as a starting point for the realization of the integrated approach, as shown above, with the hope of contributing to the studies of San Calocero and its surrounding area, thanks to the conception of a new kind of information.

To finally sum up, the main goal of the study can be summarized as follows:

(i) Knowledge for preservation - the study can help understand the most appropriate means for a conservation plan, considering that each method and tool is an 'ongoing process', and so it could be improved and replaced by others;

(ii) Knowledge for assessment - the study can help estimate the possible future changes. How does the transformation of

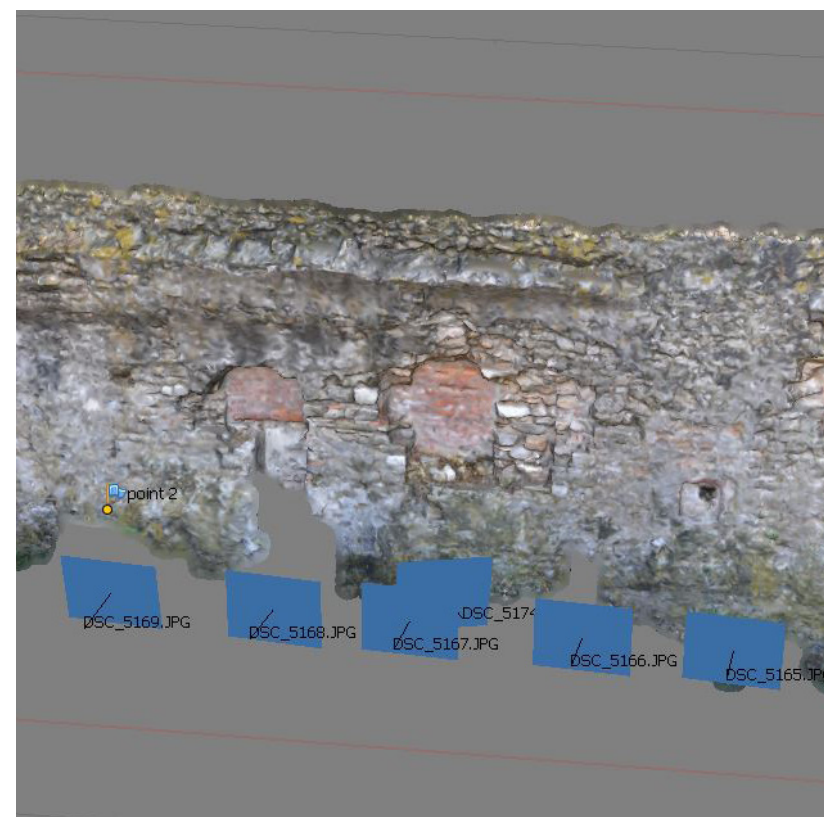

Figure 7. Perimetral wall in the Agisoft PhotoScan environment 
the environment influence the site? Which is the best way to guarantee the fruition of the area by researchers and tourists? (iii) Knowledge for prevention - the methodology can be reused in other similar cases and can help the creation of thematic maps of this territory, such as the building risk management plan.

\section{ACKNOWLEDGEMENTS}

Special thanks go to prof. Alberto Grimoldi and prof. Raffaella Brumana, Fabrizio Banfi, Luigi Barazzetti, Fabio Roncoroni (Gicarus Lab team) who supported this research; Josepha Costa Restagno and Camillo Restagno who helped with the historical research in the Peloso Cepolla archive.

\section{REFERENCES}

\subsection{References from Journals}

Del Curto D., Grimoldi A., 2010-2011. Modelli informativi 'predigitali' e loro recenti sviluppi. Dal Raumbuch al BIM. Built Heritage Information Modeling.

Lamboglia N., 1947. Gli scavi nella zona paleocristiana di S. Calocero (Albenga). Rivista di Studi Liguri, anno XIII, pp. 141183.

Lamboglia N., 1970. La topografia e stratigrafia di Albingaunum dopo gli scavi 1955-1956. Rivista di Studi Liguri (1-3), pp. 2362 .

\subsection{References from Books}

Arobba, D., Caramiello, R., Firpo, M. 2004. Contributi paleobotanici alla storia dell'evoluzione di una pianura costiera: il caso di Albenga. In: I Liguri. Un antico popolo europeo tra Alpi e Mediterraneo, de Marinis Raffaele C., Spadea G., Skira, 2004, pp. 76-78.

Arobba, D., Firpo, M., Massabò, B., Piccazzo, M., Poggi, F.,
Ramella, A., 2006. Geoarcheologia del sistema deltizio del fiume Centa (Albenga-Liguria Occidentale). In: Archeologie. Studi in onore di Tiziano Mannoni, Cucuzza N., Medri M., Edipuglia, pp. $25-28$.

Boato A., 2008. L'archeologia in architettura, Marsilio Editore, Venezia.

De Mattia D., 2012. Architettura antica e progetto: dalla Bauforschung al progetto architettonico in area archeologica, Gangemi, Roma.

Embiraco P. G., 2010. Il corpo e il luogo: l'evoluzione del culto di San Calocero nel Basso Medioevo. In: Albenga. Un antico spazio cristiano. Chiesa e monastero di San Calocero al Monte, Fratelli Frilli Editori, Genova, pp. 177-179.

Gallina D., 2012. Sillogismo deduttivo o abduzione? Alcune proposte per l'abbandono/superamento del matrix di Harris nell'analisi dell'architettura. In: VI Congresso Nazionale di Archeologia Medievale, L'Aquila, 12-15 settembre 2012, All'Insegna del Giglio, Firenze, pp. 75-81.

Gavinelli S., 2010. Intitolazione, culto martiriale di San Calocero e tradizione delle reliquie. In: Albenga. Un antico spazio cristiano. Chiesa e monastero di San Calocero al Monte, Fratelli Frilli Editori, Genova, pp. 39-45.

Landi S., 2010. L'area superiore del complesso di San Calocero,. In: Albenga. Un antico spazio cristiano. Chiesa e monastero di San Calocero al Monte, Fratelli Frilli Editori, Genova, pp. 233236.

Massabò B., 2010. Topografia di Albenga romana. In: Albenga. Un antico spazio cristiano. Chiesa e monastero di San Calocero al Monte, Fratelli Frilli Editori, Genova, pp. 73-77.

Paltineri S., 2007. Lamboglia scavatore, in Ancora su i Liguri. Un antico popolo europeo tra Alpi e Mediterraneo, de Marinis

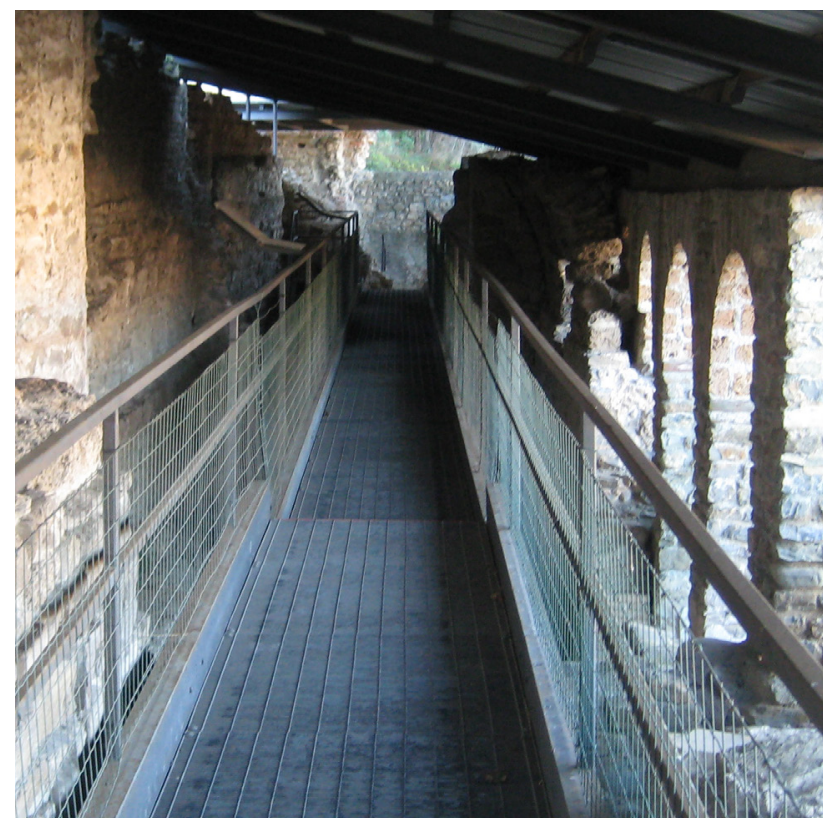

Figure 9. San Calocero, 'criptoportico' (January 2017 by Chiara Stanga)

(Archivio Istituto Internazionale di Studi Liguri, Fondo D’Aste) 
Raffaele C., Spadea G., De Ferrari, pp. 256-257.

Pergola P., 2010. Albenga alla fine dell'antichità e durante l'Altomedioevo: proposte per un'immagine della città. In: Albenga. Un antico spazio cristiano. Chiesa e monastero di San Calocero al Monte, Fratelli Frilli Editori, Genova, pp. 31-37.

Pergola P., 2010. Nascita e primo sviluppo del culto attorno alla sepoltura del martire Calocero (fonti letterarie e archeologiche). In: Albenga. Un antico spazio cristiano. Chiesa e monastero di San Calocero al Monte, Fratelli Frilli Editori, Genova, pp. 113118.

Quaini M., 1986. Il territorio di Albenga: quattro secoli di cartografia. In: Carte e cartografi in Liguria, Quaini M., Sagep Editrice, Genova, pp. 119-160.

Roascio S., 2010. Gli interventi di scavo di Nino Lamboglia: metodologie, risultati, revisioni. In: Albenga. Un antico spazio cristiano. Chiesa e monastero di San Calocero al Monte, Fratelli Frilli Editori, Genova, pp. 47-58.

Roascio S., Gavagnin S., 2010. I resti in elevato del complesso: lettura archeologica dei volumi e delle murature. In: Albenga. Un antico spazio cristiano. Chiesa e monastero di San Calocero al Monte, Fratelli Frilli Editori, Genova, pp. 211-231.

Schmidt H., 2002. Building research from past to present. The development of methods in Germany since the 19th century. In: Preparatory Architectural Investigation in the Restoration of Historical Buildings, de Jonge K. and van Balen K., Leuven University Press, Belgio, pp. 15-29.

Solarino S., 2007. Il terremoto del 23 Febbraio 1887 in Liguria Occidentale. Descrizioni, considerazioni e prevenzione 120 anni dopo il grande evento, Memoria in occasione della mostra "Terremoti: conoscerli per difendersi", Genova, 19 Marzo - 27 Maggio 2007 Museo Civico di Storia Naturale "Giacomo Doria", http://www.earth-prints.org/bitstream/2122/8207/1/libroA5.pdf.

Spadea Noviero G., Pergola P., Roascio S., 2010. Albenga. Un antico spazio cristiano. Chiesa e monastero di San Calocero al Monte, Fratelli Frilli Editori, Genova.

Vignola M., 2010. Letture e riletture delle fonti archivistiche. In: Albenga. Un antico spazio cristiano. Chiesa e monastero di San Calocero al Monte, Fratelli Frilli Editori, Genova, pp. 249-256.

\subsection{References from Website}

Borea d'Olmo G., Il manoscritto Borea. Cronache di Sanremo e della Liguria occidentale, http://www.cultura-barocca.com/ abczeta/absi.htm.

\subsection{References from Archives}

Archivio Istituto Internazionale di Studi Liguri, Scritti del Canonico Leone Raimondi, manoscritto 44, Appunti sulla Chiesa di S. Calocero.

Archivio Istituto Internazionale di Studi Liguri, Fondo D’Aste, Filza 5, manoscritto 9, Vendita 1607 fatta dai MM Protettori del Ven Monastero di S. Calocero al M. Prospero Cepolla, delle case, edifici, terre costituenti l'antico Monastero della Doria per 450 scudi da L. 4. 